\title{
SOME VENTIFACTS FOUND NEAR RECENT AND FOSSIL COASTAL DUNES IN FINLAND
}

\author{
J. J. DONNER and MARJA SIMOLA
}

\begin{abstract}
DONNER, J. J. and SIMOLA, MARJA 1977: Some ventifacts found near recent and fossil coastal dunes in Finland. Bull. Geol. Soc. Finland 49: $19-23$.

During the Holocene relative uplift of land in Finland coastal dunes were formed at various altitudes in areas earlier submerged. Some ventifacts found near these dunes, the oldest being about 4000 years old, are described from the Hanko (Hangö) peninsula and from Kalajoki in Ostrobothnia. The hard rock ventifacts have a shiny upper surface with no facets developed.
\end{abstract}

J. J. Donner and Marja Simola, Department of Geology and Palaeontology, University of Helsinki, SF-00170 Helsinki 17, Finland.

Stones affected by sand blasting in areas with former or recent eolian activity have the surface typical for ventifacts, some having clear facets and therefore called dreikanter. However, as Cailleux (1973 p. 53) points out »la forme en dreikanter n'a rien de caractéristique, tous les auteurs qui ont étudié la question sur le terrain en sont d'accord. Ce qui est caractéristique, c'est d'abord l'état de surface, paraissant brillant au soleil —-》. De Geer (1886) described wind-polished stones found in dune areas in Skåne and Halland in South Sweden and similar stones were described by Fegraeus (1886) as occuring near the dunes on the Island of Gotska Sandön north of Gotland. De Geer observed that no facets were developed on those stones which rested on sand because the position of the stones has changed during the time they have been subject to sand blasting. Only stones more firmly attached to the ground have clear facets. Further, the stones are usually polished only on one side in contrast to ventifacts formed in areas with intense cryoturbation, where several sides have been polished because the stones have been turned round on an unstable surface (Cailleux 1973).

Large areas of southern and central Finland were submerged during early Holocene times. When, as a result of isostatic uplift the areas emerged from the Baltic, dunes were formed on the beaches where suitable material, particularly from glaciofluvial formations or river sediments, was available for wind transport. As the shoreline receded the beach dunes soon became covered by vegetation and inactive, and new dunes were built up on the freshly exposed beaches. Thus, 
there is a series of fossil coastal dunes in areas below the highest beach level, i.e. the limit of submergence, reaching an altitude of more than $200 \mathrm{~m}$ in those parts of the country with the greatest uplift. In addition, dunes were formed in the periglacial zone on dry land outside the retreating ice margin during the Late Weichselian and Early Flandrian substages, particularly in North Karelia and Lapland. But even their distribution is partly governed by the closeness of the shoreline at that time.

As ventifacts have not previously been described from the Finnish dune areas a few

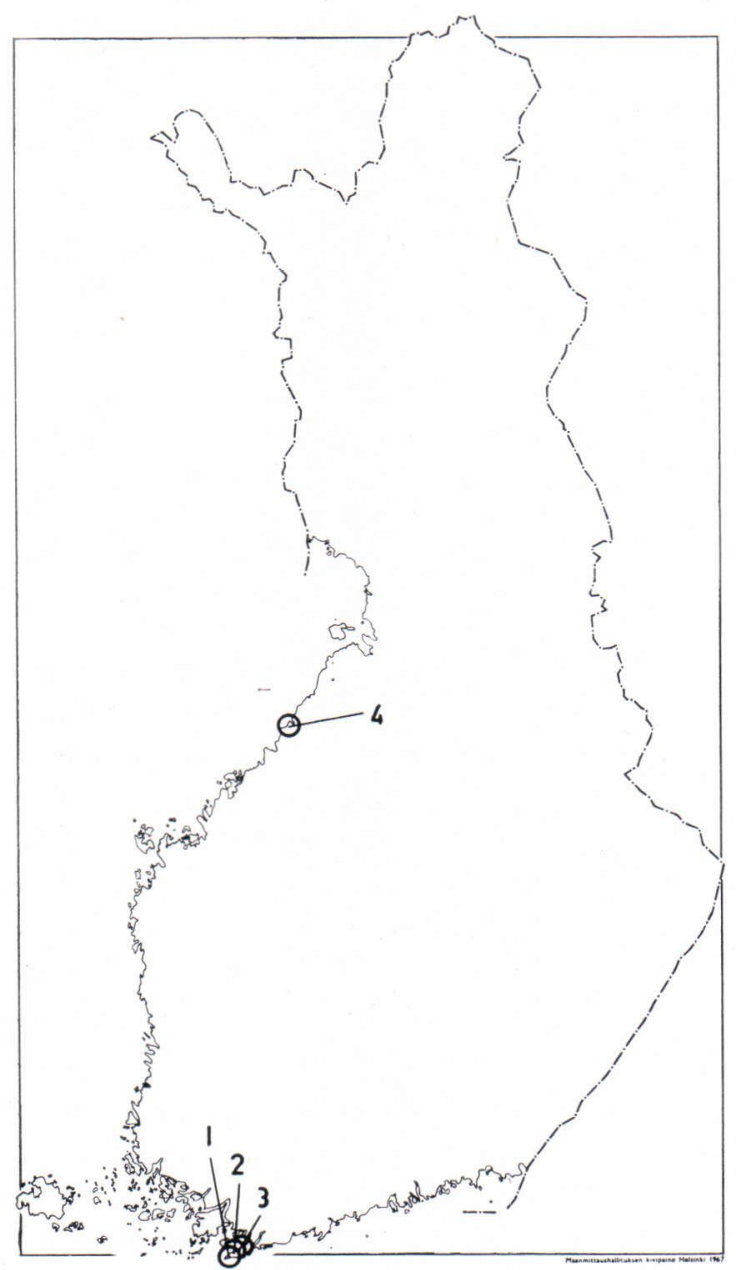

Fig. 1. Sites with ventifacts. examples are here given of some finds from 1975 at or near the present coastline. The sites at which they were found are shown in Fig. 1. The first three are from the Hanko (Hangö) peninsula, which is largely built up by the glaciofluvial material of the end-moraine of the first Salpausselkä, whereas the fourth site is in Ostrobothnia. The sites are the following:

1. Hanko (Hangö), $1: 20,000$ map sheet no. 201108, grid reference $6635.3-24^{\circ}-444.4$, altitude $<5$ $\mathrm{m}$. In the bay of Kolaviken in the outskirts of Hanko, west of Tulludden, there are several beach dunes about $1 \mathrm{~m}$ high a few metres above the present beach. The dunes are in a pine forest with a patchy ground vegetation, mainly with lichens and bearberry (Arctostaphylos uva ursi).

2. Sandö, Hanko (Hangö) peninsula, $1: 20,000$ map sheet no. 201109, grid reference $6640.6-24^{\circ}$ -449.2 , altitude $15 \mathrm{~m}$. Fossil dune about $1.5 \mathrm{~m}$ high, cut by the main road. Pine forest with bearberry and cowberry (Vaccinum vitis-idaea).

3. Koverhar, Lappohja (Lappvik), Hanko (Hangö) peninsula, $1: 20,000$ map sheet no. 201112, grid reference $6643.6-24^{\circ}-455.2$, altitude $20 \mathrm{~m}$. Large fossil dune about $2-3 \mathrm{~m}$ high, seen in gravel pit section east of the main road, resting on an even surface of coarse glaciofluvial material. Vegetation same as at site 2.

4. Kalajoki, $1: 20,000$ map sheet no. 241312 , grid reference $7126.8-24^{\circ}-491.4$, altitude $<5 \mathrm{~m}$. The present gently rising beach consists of coarse sand with some stones up to an altitude of about $5 \mathrm{~m}$. Above this a sub-recent dune about $10 \mathrm{~m}$ high along the beach, partly covered by lyme-grass (Elymus arenarius).

For stones to be effectively polished by sand blasting of the eolian material accumulated in the dunes mentioned above the stones must have been for some time at the surface over which the sand moved. It is therefore natural that only a small percentage of stones in a dune area have developed into ventifacts. They were, however, found at all sites where they were looked for and no attempt was made to collect a great number of them. Those found at sites 1, 2 and 4 were 


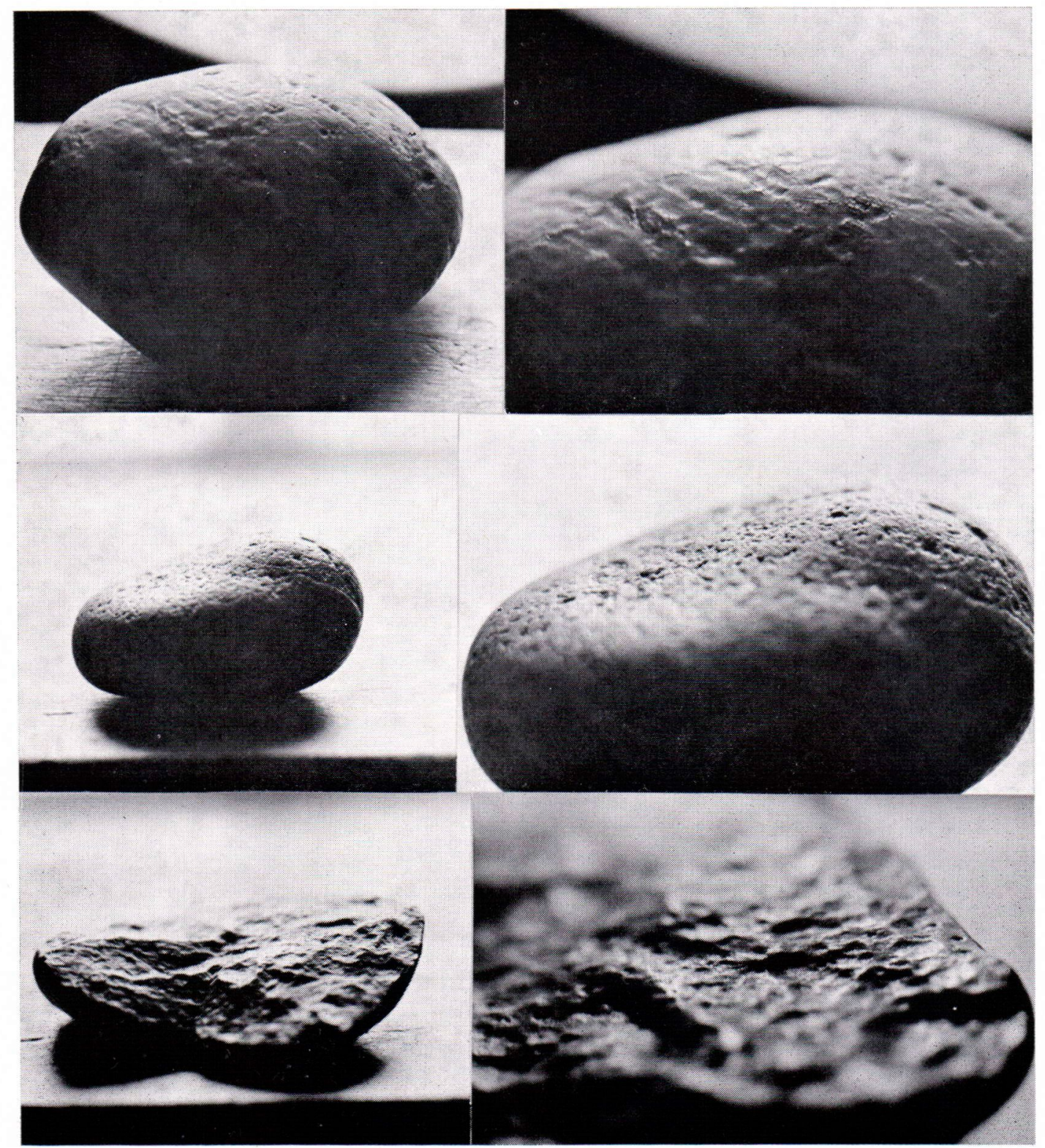

Fig. 2. Photographs of three ventifacts, with closeups on the right, from sites 2,3 and 4 from top to bottom as listed in text.

all close to the dunes on their windward side whereas that from site 3 was in the lower part of the dune sand, as exposed in the section. The size of the ventifacts and the rocks they consist of are listed below:

Site $1.4 \times 3 \times 2 \mathrm{~cm}$, red granite 1. $5 \times 4 \times 2 \mathrm{~cm}$, gneiss
2. $5 \times 4 \times 2.5 \mathrm{~cm}$, quartz-feldspar-pegmatite (photo in Fig. 2)

3. $6 \times 4.5 \times 2.5 \mathrm{~cm}$, red granite (photo in Fig. 2)

4. $8.5 \times 6.5 \times 1.5 \mathrm{~cm}$, red granite (photo in Fig. 2) 
4. $8 \times 6 \times 2 \mathrm{~cm}$, red granite

4. $4.5 \times 4 \times 1 \mathrm{~cm}$, red granite

All ventifacts consist of cobbles or coarse pebbles of the local Precambrian rocks, the size variation being rather small. One cobble from site 4 (see Fig. 2) is a ventifact formed from one half of an originally larger cobble. The uneven surface of the cobble has been wind-polished and has irregular facets on the surface. The rounded underside of the ventifact shows some effect of wind blasting. All other ventifacts are well rounded and are clearly wind-polished only on one side, as seen from the two examples in Fig. 2. None of the cobbles or pebbles have changed shape because of the polishing but they all have the shiny surface typical for ventifacts. The unaffected sides of them have a mat surface. The comparatively weak influence of sand blasting on the ventifacts resting on a loose unstable surface has not been able to form detailed morphological features on the basis of which former wind-directions could be determined, as for instance on the wind-polished boulders and stones in Weichselian interstadial deposits near Gothenburg in Sweden (Hillefors 1961, 1964).

In addition to the mechanical effect of sand blasting on the ventifacts some of the shine can also be caused by weathering processes causing the deposition of manganese and iron on the surface, resulting in a desert varnish (Engel and Sharp 1958). On the second ventifact in Fig. 2 from site 3 there is a brown colouring of the upper shiny side which is missing on the lower side without polish. There is thus on this ventifact, and also less clearly on some of the others, the first indication of a varnish caused by chemical processes related to those found in deserts.

Fig. 3 gives cumulative curves for the dune material in the areas with ventifacts. The curves of 15 samples analyzed of eolian material from Hanko around site 1 (anal. by

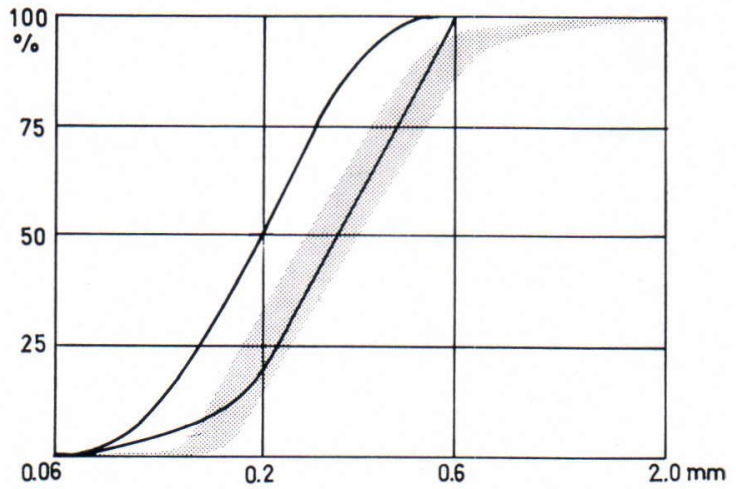

Fig. 3. Cumulative curves of dune material. Curves of samples from Hanko (site 1) fall within shaded area. The two drawn curves are from Kalajoki (site 4).

Marja Simola) fall within the shaded area and the two curves drawn in Fig. 3 are from earlier published results from the Kalajoki dunes (Lemberg 1933, Okko 1949). One of these represents medium sand (ø $0.20-0.60$ $\mathrm{mm}$ ) and the other represents a material between medium and fine sand. All samples from Hanko are medium sand. According to the sorting index of Trask (1932) and the classification of Sindowski (1961) the material in both samples from Kalajoki and in 13 from Hanko are well sorted and in the two remaining samples from Hanko moderately sorted. The eolian material in the dunes was transported by the winds from the sea, away from the beach over the cobbles and pebbles. The most frequent summer winds on the Hanko peninsula are south-westerly and in Kalajoki westerly, the mean velocities being about 6 $\mathrm{m} / \mathrm{sec}$, storms with velocities exceeding 14 $\mathrm{m} / \mathrm{sec}$. being rare in summer (Keränen and Korhonen 1952, Atlas of Finland 1960).

The ages of the coastal dunes at which the ventifacts were found can roughly be calculated using the amount of the relative uplift of land and the altitudes of the sites. A linear extrapolation based on the present uplift of land (Kääriäinen 1966) cannot, however, be used because it must be assumed that the re- 
lative lowering of sea level has slowed down during the last few thousand years. This can be seen already from the geologically dated altitude of the upper limit of the Litorina Sea from about 7000 B.P. (Eronen 1974). A linear regression from this limit, which at Hanko peninsula is about $39 \mathrm{~m}$, would give an age of about 3700 years for the dune at $20 \mathrm{~m}$ (site 3), of about 2800 years for the dune at $15 \mathrm{~m}$ (site 2) and about 900 years for the dunes at about $5 \mathrm{~m}$ (site 1). At Kalajoki the limit of the Litorina Sea is at about 108 $\mathrm{m}$, which gives an age of about 300 years for the large dune above the $5 \mathrm{~m}$ contour (site 4) These are minimum ages, the true ages being somewhat higher. The oldest dune is probably about 4000 years old on the Hanko peninsula, and the others also somewhat older than the dates given above. The ventifacts have thus been preserved since the time of the formation of these dunes. It has been estimated that wind-abrasion on hard-rock stones on modern beaches requires about 100 years, the formation of facets e'ven more (Flint 1971). Ventifacts like those described here may however require less than 100 years to be formed.

In contrast to the Holocene ventifacts described above several ventifacts have been found in Alpua in Vihanti, about $60 \mathrm{~km}$ north-east of Kalajoki (found by A. Lumiaho, oral communication by P. Markkanen). Some of them consist of quartzite and most of them have clearly developed facets. They are all worn and come from the local late Precambrian bedrock, which partly consists of quartzites, sandstones and conglomerates. Material from these rocks has been incorporated in the till (Hyyppä 1948).

\section{References}

Atlas of Finland 1960. Geogr. Soc. of Finland.

Cailleux, A. (1973) Répartition et signification des différents critères d'éolisation périglaciaire. Biul. perygl. 23: 51-63.

De Geer, G. (1886) Om vindnötta stenar. Geol. Fören. Stockholm Förh. 8(7): 501-513.

Engel, C. G. and Sharp, R. P. (1958) Chemical data on desert varnish. Bull. Geol. Soc. Am. 69: $487-518$.

Eronen, M. (1974) The history of the Litorina Sea and associated Holocene events. Commentat. Physico-Math. 44(4): 79-195.

Fegraeus, T. (1886) Sandslipade stenar från Gotska Sandön. Geol. Fören. Stockholm Förh. 8(7): $514-518$.

Flint, R. F. (1971) Glacial and Quaternary Geology. John Wiley \& Sons, Inc., New York. 892 p.

Hillefors, $A$. (1961) Om vindslipade blockhorisonter i Dösebackagruppens bildningar. Medd. Geogr. Fören. Göteborg, Gothia 9: 73-93.

- (1964) Vindslipat flyttblock från Ellesbo och Västsveriges glacialhistoriska utveckling. Göteborgs Naturhistoriska Museum, Årstryck 1964: $29-42$.
Hyyppä, E. (1948) Tracing the source of the pyrite stones from Vihanti on the basis of glacial geology. Bull. Comm. Géol. Finlande 142: 97122.

Keränen, J. and Korhonen, V. V. (1952) Climate (in: Suomi, a general handbook on the geography of Finland). Fennia 72(9): 100-128.

Kääriäinen, E. (1966) The second levelling of Finland in 1935-1955. Veröffentl. Finnischen Geodätischen Institutes $61.313 \mathrm{p}$.

Lemberg, B. (1933) Über die Vegetation der Flugsandsgebiete an den Küsten Finnlands. I Teil: Die Sukzession. Acta Botanica Fennica 12. 143 p.

Okko, V. (1949) Maalajikartan selitys, lehti B 4, Kokkola. Suomen geologinen yleiskartta. 108 p.

Sindowski, K.-H. (1961) Mineralogische, petrographische und geochemische Untersuchungsmethoden. Lehrbuch der angewandten Geologie, Stuttgart: $161-182$.

Trask, P. D. (1932) Origin and environment of source sediments of petroleum. Gulf Publishing Company, Houston. 323 p.

Manuscript received, March 30, 1976. 